\title{
PERANCANGAN APLIKASI PENJUALAN TOKO CITRA BARU BERBASIS APLIKASI MOBILE
}

\section{DESIGNING TOKO CITRA BARU SALES APPLICATION BASED ON MOBILE APPLICATION}

\author{
Ignatius Adrian Mastan ${ }^{1 *}$ \\ 1) Program Studi Sistem Informasi, Universitas Bunda Mulia, Jakarta
}

Diterima 22 Maret 2021 / Disetujui 29 Maret 2021

\begin{abstract}
The development of information technology has changed all business processes, especially within organizations or companies. One of the organizations or companies affected in this case is Toko Citra Baru. Toko Citra Baru is an LPG agent, gallons of drinking water and daily necessities. In its operational activities, Toko Citra Baru accepts customer orders from the telephone and sends these orders to the customer's location or customers can come directly to the store. Toko Citra Baru in its operational activities encountered several problems, namely frequent errors in recording customer orders, errors in recording shipping addresses, and difficulties in recapitulating sales transactions. Based on these problems, a mobile application-based sales application was created using the System Development Life Cycle (SDLC) method until the design stage. The purpose of this application design is to solve the various problems faced by the Toko Citra Baru. By using this application, customers can order goods through the application, as well as select goods and make payments using a variety of methods, namely COD (Cash On Delivery), e-wallets and transfers so that it is faster and more practical, as well as helping Toko Citra Baru to accept customer orders more easily. The making of this application is based on a mobile application because it is easier to use and adapts to user needs.
\end{abstract}

Keywords: sales application, mobile application, Toko Citra Baru

\section{ABSTRAK}

Perkembangan teknologi informasi telah merubah segala proses bisnis, terutama di dalam organisasi atau perusahaan. Salah satu organisasi atau perusahaan yang terdampak dalam hal ini adalah Toko Citra Baru. Toko Citra Baru merupakan sebuah agen LPG, air minum galon dan kebutuhan sehari hari. Dalam kegiatan operasionalnya, Toko Citra Baru menerima pesanan pelanggan dari telepon dan mengirimkan pesanan tersebut ke lokasi pelanggan atau pelanggan dapat langsung datang ke toko. Toko Citra Baru dalam kegiatan operasionalnya menemui beberapa permasalahan, yaitu sering terjadi kesalahan dalam pencatatan pesanan pelanggan, kesalahan dalam mencatat alamat pengiriman, serta kesulitan dalam merekapitulasi transaksi penjualan. Berdasarkan permasalahan tersebut dibuatlah sebuah aplikasi penjualan berbasis aplikasi mobile dengan menggunakan metode System Development Life Cycle (SDLC) sampai pada tahap desain. Perancangan aplikasi ini mempunyai tujuan untuk menyelesaikan berbagai macam permasalahan yang dihadapi Toko Citra Baru. Dengan menggunakan aplikasi ini, pelanggan dapat melakukan pemesanan barang lewat aplikasi, serta memilih barang dan melakukan pembayaran menggunakan berbagai macam cara, yaitu COD (Cash On Delivery), e-wallet dan transfer sehingga lebih cepat dan praktis, serta membantu Toko Citra Baru untuk menerima pesanan pelanggan dengan lebih mudah. Pembuatan aplikasi ini berbasis aplikasi mobile dikarenakan lebih mudah digunakan dan menyesuaikan dengan kebutuhan pengguna.

Kata Kunci : aplikasi penjualan, mobile application, Toko Citra Baru

*Korespondensi Penulis :

E-mail: Ignatius@mti.gadjahmada.edu 


\section{PENDAHULUAN}

Perkembangan teknologi informasi telah merubah segala proses bisnis, terutama di dalam organisasi atau perusahaan. Salah satu organisasi atau perusahaan yang terdampak dalam hal ini adalah Toko Citra Baru. Toko Citra Baru berada di kawasan Surabaya Timur dengan melayani pelanggan dari beberapa pelanggan dari perumahan di Surabaya Timur. Toko Citra Baru merupakan sebuah agen LPG (untuk $12 \mathrm{~kg}$ dan $3 \mathrm{~kg}$ ), air minum galon (aqua, club, total, vit, cleo) dan kebutuhan sehari hari (beras, minyak, telor, sabun cuci). Dalam kegiatan operasionalnya, Toko Citra Baru menerima pesanan pelanggan dari telepon dan mengirimkan pesanan tersebut ke lokasi pelanggan atau pelanggan dapat langsung datang ke toko.

Toko Citra Baru dalam kegiatan operasionalnya menemui beberapa permasalahan, yaitu sering terjadi kesalahan dalam pencatatan pesanan pelanggan, kesalahan dalam mencatat alamat pengiriman, kesalahan dalam menerima pembayaran pelanggan serta kesulitan dalam merekapitulasi transaksi penjualan. Berdasarkan permasalahan tersebut dibuatlah sebuah aplikasi penjualan berbasis aplikasi mobile dengan menggunakan metode System Development Life Cycle (SDLC) sampai pada tahap desain.

Aplikasi penjualan ini memiliki beberapa fungsi, yaitu pendaftaran pelanggan, pemilihan produk, pemesanan produk, dan pembayaran transaksi. Perancangan aplikasi ini mempunyai tujuan untuk menyelesaikan berbagai macam permasalahan yang dihadapi Toko Citra Baru. Dengan menggunakan aplikasi ini, pelanggan dapat melakukan pemesanan barang lewat aplikasi, serta memilih barang dan melakukan pembayaran menggunakan berbagai macam cara, yaitu COD (Cash On
Delivery), e-wallet dan transfer sehingga lebih cepat dan praktis, serta membantu Toko Citra Baru untuk menerima pesanan pelanggan dengan lebih mudah. Pembuatan aplikasi ini berbasis aplikasi mobile dikarenakan lebih mudah digunakan dan menyesuaikan dengan kebutuhan pengguna.

\section{TINJAUAN PUSTAKA}

\section{A. Penelitian Terdahulu}

Penelitian Syahrul (2012) dengan judul Perancangan Sistem Informasi Penjualan Pulsa Berbasis Android. Hasil penelitiannya adalah berupa produk sistem informasi penjualan pulsa. Dengan sistem informasi penjualan pulsa yang dibuat diharapkan meminimalisir kesalahan dalam proses transaksi penjualan dan pembuatan laporan pendapatan lebih cepat.

Penelitian Poundra (2013) dengan judul Aplikasi Toko Tas Online Berbasis Android. Hasil penelitiannya adalah pengembangan aplikasi pada smartphone Android dapat digunakan sebagai peluang usaha guna memanfaatkan tren perdagangan yaitu aplikasi toko tas online. Aplikasi Android yang dibuat dapat menampilkan product dari database server

\section{B. Perancangan}

Perancangan adalah Suatu kegiatan yang memiliki tujuan untuk mendesign sistem baru yang dapat menyelesaikan masalah-masalah yang dihadapi perusahaan yang diperoleh dari pemilihan alternatif sistem yang terbaik (Ladjamudin, 2005).

\section{Aplikasi}

Menurut Sutabri (2012) Pengertian Aplikasi adalah satu unit perangkat lunak yang dibuat untuk melayani kebutuhan akan beberapa aktivitas.

\section{Mobile Commerce}

M-Commerce adalah pengembangan dari e-commerce yakni proses transaksi bisnis meliputi pembelian, 
penjualan atau pertukaran barang dan jasa serta informasi yang berjalan dengan menggunakan jaringan telekomunikasi mobile atau wireless (Satoto, 2013).

\section{E. Android}

Android merupakan sistem operasi berbasis linux yang digunakan untuk perangkat mobile atau perangkat tablet (PDA). Android menyediakan platform terbuka bagi para pengembang untuk mengembangkan aplikasi buatan sendiri yang membuat android menjadi sistem operasi mobile yang populer hingga saat ini. Android didirikan pada tahun 2003 oleh Andy Rubin, Nick Sears, Rich Miner dan Chris White yang kemudian dibeli oleh Google pada bulan Juli 2005 (Sadeli, 2014).

Android adalah sebuah sistem operasi untuk perangkat mobile berbasis linux yang mencakup sistem operasi, middlewere dan aplikasi. Android menyediakan platform terbuka bagi para pengembang untuk membuat aplikasi mereka. Awalnya, Google Inc. membeli Android Inc. yang merupakan pendatang baru yang membuat software untuk ponsel/smartphone. Kemudian untuk mengembangkan Android, dibentuklah Open Handset Alliance, konsorsium dari 34 perusahaan hardware, software, dan telekomunikasi, termasuk Google, HTC, Intel, Motorola, Qualcomm, T-Mobile, dan Nvidia (Hidayat, 2008).

\section{F. Mobile}

Mobile dapat diartikan sebagai perpindahan yang mudah dari satu tempat ke tempat yang lain, misalnya telepon mobile berarti bahwa terminal telepon yang dapat berpindah dengan mudah dari satu tempat ke tempat lain tanpa terjadi pemutusan atau terputusnya komunikasi. Sistem Aplikasi mobile merupakan aplikasi yang dapat digunakan walaupun pengguna berpindah dengan mudah dari satu tempat ketempat lain lain tanpa terjadi pemutusan atau terputusnya komunikasi. Aplikasi ini dapat diakses melalui perangkat nirkabel seperti pager, seperti telepon seluler dan PDA (Setyadi, 2013).

\section{G. Penjualan}

Menurut Kotler (2008:8), Penjualan adalah proses sosial manajerial dimana individu dan kelompok mendapatkan apa yang mereka butuhkan dan inginkan, menciptakan, menawarkan, dan mempertukarkan produk yang bernilai dengan pihak lain.

\section{H. Jenis Penjualan}

Menurut Sumarni (2003:321) Jenis Penjualan dapat di bedakan menjadi :

1. Penjualan Langsung, yaitu suatu proses membantu dan membujuk satu atau lebih calon konsumen untuk membeli barang atau jasa atau bertindak sesuai ide tertentu dengan menggunakan komunikasi tatap muka.

2. Penjualan Tidak Langsung, yaitu bentuk presentase dan promosi gagasan barang dan jasa dengan menggunakan media tertentu seperti surat kabar, majalah, radio, televisi, papan iklan, brosur dan lain-lain.

\section{Waterfall Model}

Waterfall Model SDLC (System Developement Life Cycle) adalah sebuah proses pengembangan perangkat lunak sekuensial dimana kemajuan dalam pengembangan dianggap seperti mengalir ke bawah (mirip dengan air terjun) melewati daftar fase yang harus dijalankan untuk berhasil membangun perangkat lunak komputer (Bassil, 2012:2). 


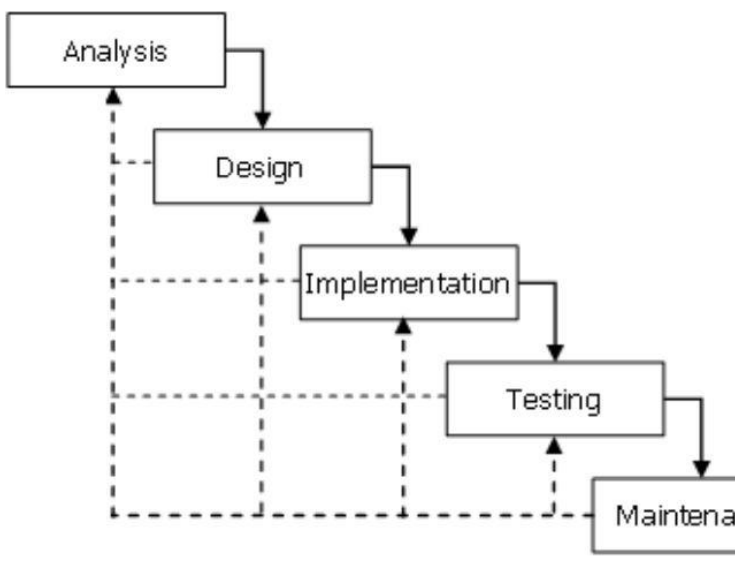

Gambar 1. Waterfall Model

(Bassil, 2012:2)

Menurut referensi Bassil (2012:2), Waterfall Model terdiri dari lima fase, yaitu

1. Analysis

Sering dikenal juga sebagai SRS (Software Requirements Specification) adalah deskripsi lengkap dan komprehensif tentang perilaku perangkat lunak yang akan dikembangkan. Ini melibatkan analis sistem dan bisnis untuk mendefinisikan persyaratan, baik fungsional maupun non-fungsional. Biasanya, kebutuhan fungsional didefinisikan dengan menggunakan kasus-kasus penggunaan yang menggambarkan interaksi pengguna dengan perangkat lunak. Halhal tersebut termasuk persyaratan seperti tujuan, ruang lingkup, perspektif, fungsi, atribut perangkat lunak, karakteristik pengguna, spesifikasi fungsionalitas, kebutuhan antarmuka atau tampilan, dan kebutuhan basis data. Sebaliknya, kebutuhan non-fungsional mengacu pada berbagai kriteria, batasan, dan kebutuhan yang menentukan desain dan operasi pada perangkat lunak daripada perilaku tertentu. Hal ini termasuk beberapa properti, seperti: keandalan, dapat diuji coba, ketersediaan, pemeliharaan, kinerja, dan standar kualitas.

\section{Design}

Fase ini adalah proses perencanaan dan pemecahan masalah untuk solusi perangkat lunak. Hal ini melibatkan pengembang dan desainer perangkat lunak untuk menentukan rencana dalam membuat sebuah solusi yang meliputi desain algoritma, desain arsitektur perangkat lunak, skema konseptual database dan desain diagram logis, desain konsep, desain antarmuka pengguna grafis, dan definisi struktur data.

3. Implementation

Fase ini mengacu pada realisasi terhadap kebutuhan bisnis dan spesifikasi desain menjadi suatu program yang dapat dieksekusi secara konkret, database, situs web, atau komponen perangkat lunak melalui pemrograman dan penyebaran. Fase ini merupakan tempat dimana kode asli ditulis dan dikompilasi menjadi suatu aplikasi operasional, dan dimana file database dan teks dibuat. Dengan kata lain, fase ini adalah proses mengubah seluruh kebutuhan dan cetak biru (blueprint) menjadi lingkungan produksi.

4. Testing

Fase ini juga dikenal sebagai proses verifikasi dan validasi yang merupakan proses untuk memeriksa bahwa solusi perangkat lunak memenuhi persyaratan dan spesifikasi dan dapat memenuhi tujuan yang dimaksudkan. Verifikasi adalah proses mengevaluasi perangkat lunak untuk menentukan apakah produk dari fase pengembangan yang diberikan memenuhi kondisi yang dikenakan pada awal fase itu. Validasi adalah proses evaluasi perangkat lunak selama atau pada akhir proses pengembangan untuk menentukan apakah memenuhi persyaratan yang ditentukan. Selain itu, fase pengujian (testing) adalah suatu cara untuk melakukan debugging dimana bug dan gangguan sistem dapat 
ditemukan, diperbaiki, dan disempurnakan.

5. Maintenance

Fase ini adalah proses memodifikasi solusi perangkat lunak setelah pengiriman dan penerapan untuk memperbaiki hasil, memperbaiki kesalahan, dan meningkatkan kinerja dan kualitas. Kegiatan pemeliharaan tambahan dapat dilakukan dalam fase ini termasuk mengadaptasi perangkat lunak ke lingkungannya, mengakomodasi kebutuhan pengguna baru, dan meningkatkan keandalan perangkat lunak.

\section{HASIL DAN PEMBAHASAN}

\section{A. Flowchart}

Flowchart pada Gambar 3 menggambarkan beberapa proses sebagai berikut ini :

1. Proses Pendaftaran Pelanggan

Jika Pelanggan Baru, maka akan diminta untuk melakukan registrasi pelanggan

2. Proses Memilih Produk

Memilih Jenis Produk yang diinginkan, yaitu LPG, Air Galon, Kebutuhan sehari-hari.

3. Proses Memilih Jenis Pembayaran

Memilih jenis pembayaran COD, atau menggunakan e-wallet atau transfer

4. Proses Menyiapkan Produk

Berdasarkan data pemesanan dan pembayaran pelanggan, karyawan menyiapkan produk

5. Proses Mengirim Produk

Mengirim Produk dan Nota Penjualan ke Pelanggan

6. Proses Menerima Produk

Pelanggan menerima produk yang telah dipesan

7. Proses Pembayaran jika memilih COD

Pelanggan melakukan pembayaran jika memilih pembayaran diawal proses secara COD.

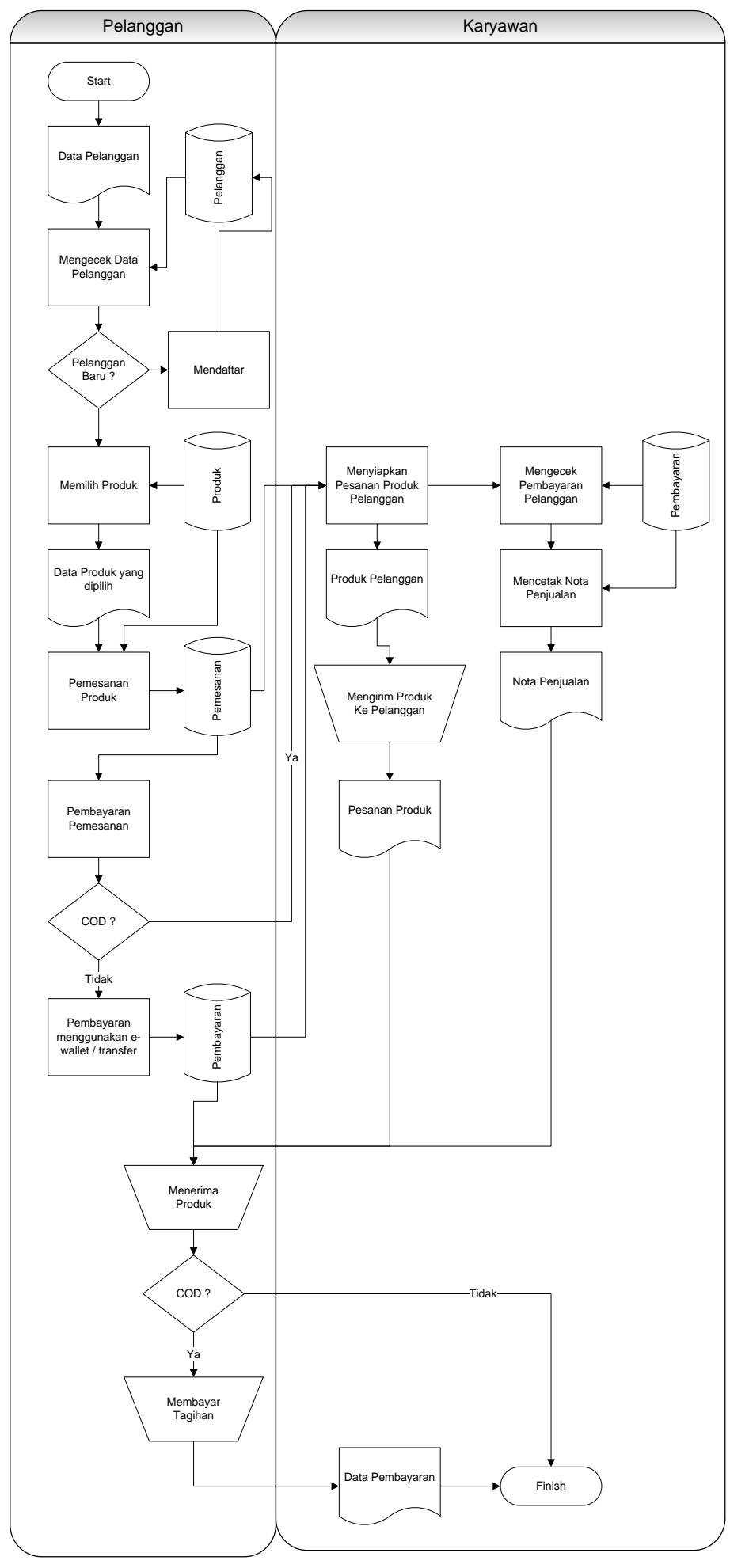

Gambar 3. Flowchart Alur Proses 
Versi Online: http://journal.ubm.ac.id/index.php/jbase DOI: http://dx.doi.org/10.30813/jbase.v4i1.2733

Hasil Penelitian
Journal of Business and Audit Information Systems

Vol 4 (No.1) : 49-56. 2021

p-ISSN: 2615-6431

e-ISSN: 2620-7907

\section{B. Entity Relationship Diagram}

Perancangan ERD bertujuan untuk memberikan gambaran mengenai database yang akan digunakan untuk menyimpan

$$
\begin{array}{|l|}
\multicolumn{1}{|c|}{\text { Pelanggan }} \\
\hline \text { Kode Pelanggan } \\
\hline \text { Nama_Pelanggan } \\
\text { Alamat_Pelanggan } \\
\text { Nomer_Telepon } \\
\text { Email } \\
\text { Password } \\
\text { Kode_Pelanggan }
\end{array}
$$

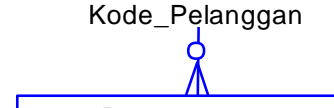

data-data yang diperlukan dalam aplikasi penjualan di Toko Citra Baru, seperti yang ditunjukkan pada Gambar 4.

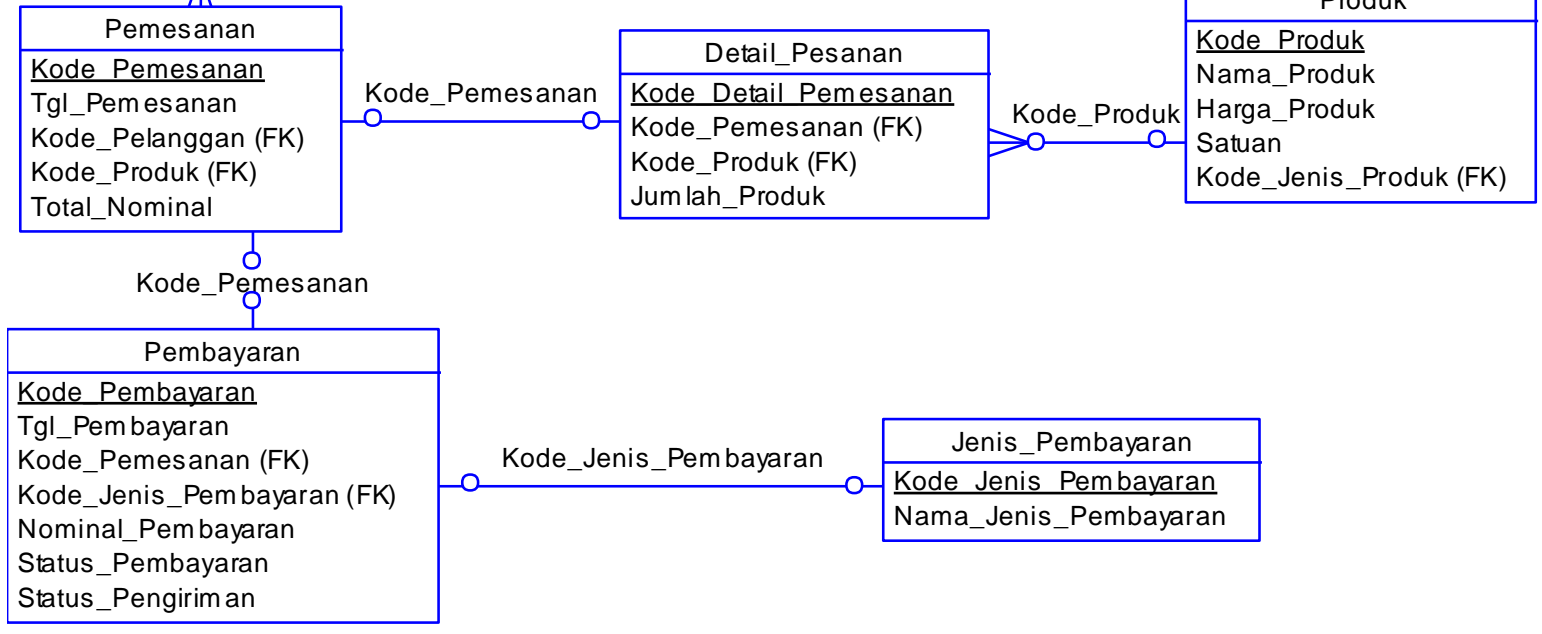

\section{Gambar 4. Entity Relationship Diagram}

\section{Desain Input Output}

Tampilan dari halaman login setelah pelanggan menginstall aplikasi dapat dilihat pada Gambar 5, dimana setiap pelanggan yang ingin masuk ke dalam aplikasi harus memiliki akses berupa email dan password yang terdaftar. Untuk pelanggan baru dapat menekan tombol Sign Up. Jika pengguna aplikasi lupa dengan password, maka pengguna bisa menekan tombol forgot password.

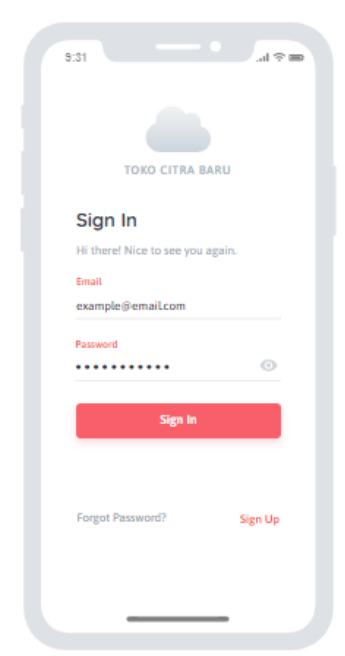

Gambar 5. Halaman Login

Halaman utama aplikasi adalah tampilan pertama yang muncul setelah sukses melakukan login, dapat dilihat pada Gambar 6, dibawah ini 


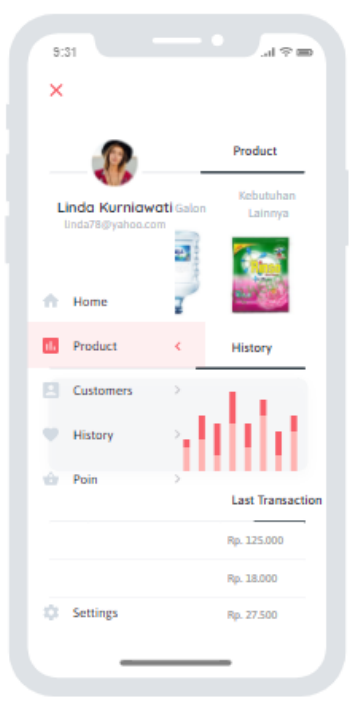

\section{Gambar 6. Halaman Utama Aplikasi}

Gambar 7 menampilkan halaman menu Produk yang berisikan jenis-jenis produk yang dijual. Pelanggan dapat memilih produk dan menentukan jumlah produk yang ingin dibeli. Jumlah produk dapat ditambah dan dikurangi sesuai dengan kebutuhan pelanggan.

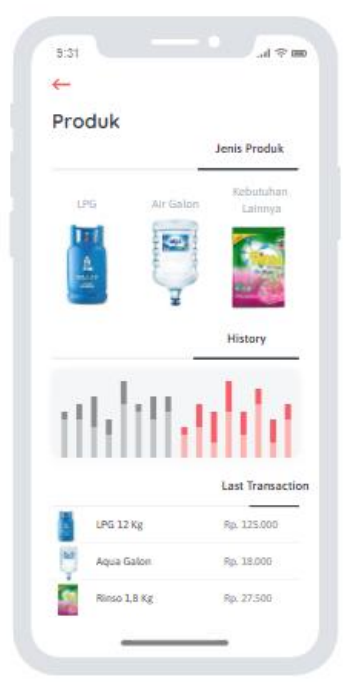

Gambar 7. Tampilan Menu Produk

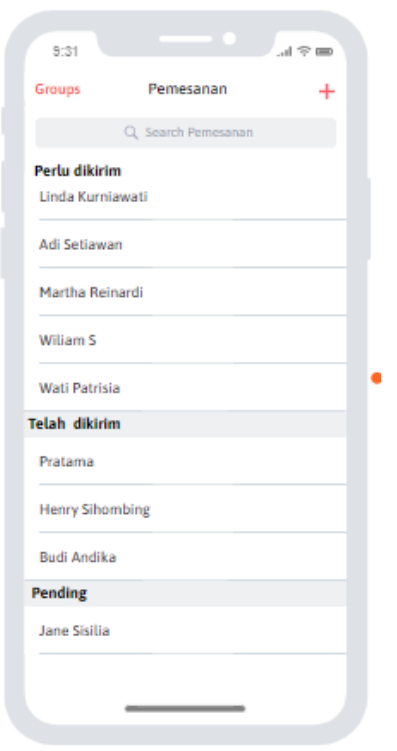

\section{Gambar 8. Tampilan Pemesanan}

Gambar 8 menampilkan halaman pemesanan pelanggan yang dilihat oleh pegawai, untuk menunjukkan daftar pelanggan yang telah melakukan pemesanan dan perlu dilakukan pengiriman barang, telah dikirim, dan pending

Gambar 9 menampilkan halaman menu pembayaran yang telah dilakukan oleh pelanggan dapat menampilkan data detail pemesanan, pembayaran dari pelanggan dan status pengiriman

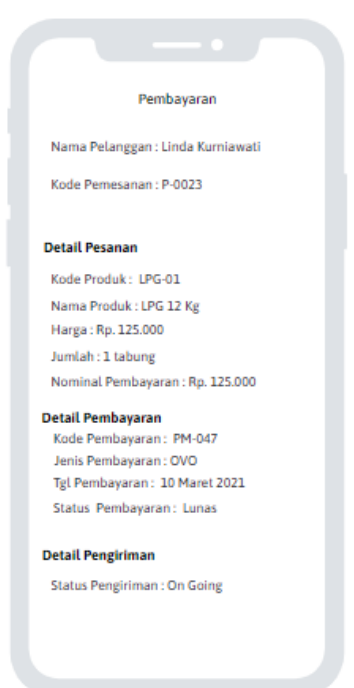

Gambar 9. Tampilan Pembayaran 


\section{KESIMPULAN}

Berdasarkan desain aplikasi tersebut, maka diambil kesimpulan dari penelitian ini sebagai berikut :

1. Dengan aplikasi penjualan ini dapat membantu mengelola data pelanggan, data produk, data pemesanan pelanggan, data pembayaran pelanggan.

2. Aplikasi penjualan ini berbasis mobile sehingga dapat diakses dimana saja dengan melakukan peng-instalasi terlebih dahulu.

3. Dengan aplikasi penjualan ini dapat membantu Toko Citra Baru dalam mengelola pemesanan dan pembayaran pelanggan dengan lebih mudah dan cepat.

\section{DAFTAR PUSTAKA}

Bassil, Youssef. 2012. A Simulation Model for the Waterfall Software Development Life Cycle. International Journal of Engineering \& Technology (iJET) 2012, Vol. 2, No. 5. ISSN: 2049-3444

Hidayat, Taufik. 2008. Panduan Membuat Toko Online dengan OSCommerce". Jakarta: Mediakita.

Kotler,Philip. 2008. Manajemen Pemasaran, Jakarta : Erlangga
Ladjamudin, Al-Bahra Bin. 2005, Analisis dan Desain Sistem Informasi, Graha Ilmu, Yogyakarta

Poundra K, P,. Petrus S,. 2013. Aplikasi Toko Tas Online Berbasis Android, Jurnal Dimensi Teknik Elektro, No. 1 Vol. 1, Hal 12-17.

Sadeli, Muhammad. 2014. Toko Buku Online dengan Android. Palembang, Indonesia: Maxikom.

Satoto, Kodrat Iman 2013. Perancangan Aplikasi Toko Online "XOLICIOUS" Berbasis Mobile Web Pada Sistem Operasi Android. Jurnal Teknologi dan Sistem Komputer, vol. 1, no. 4, p. 2.

Setyadi, Ary., \& Bhinuka, Galuh. 2013. Aplikasi pemesanan menu berbasis Android di Restoran Bumbu Desa Solo

Sumarni, Murti. 2003. Bauran Pemasaran dan Loyalitas Pelanggan, Yogyakarta : Liberty

Sutabri ,Tata. 2012. Konsep Sistem Informasi. Yogyakarta: CV Andi Offset

Syahrul M., Ahmad S,. 2013,. Perancangan Sistem Informasi Penjualan Pulsa Berbasis Android. Jurusan Manajemen Informasi, Universitas Komputer Indonesia, Bandung. 